\title{
Interactions among the toxic dinoflagellate Amphidinium carterae, the heterotrophic dinoflagellate Oxyrrhis marina, and the calanoid copepods Acartia spp.
}

\author{
Hae Jin Jeong ${ }^{1, *}$, Heonjoong Kang ${ }^{2}$, Jae Hyung Shim ${ }^{2}$, Jong Kyu Park ${ }^{3}$, \\ Jae Seong Kim ${ }^{4}$, Jae Yoon Song ${ }^{4}$, Hyuk-Jae Choi ${ }^{2}$ \\ ${ }^{1}$ Department of Oceanography, and ${ }^{4}$ Red Tide Research Center, College of Ocean Science and Technology, \\ Kunsan National University, Kunsan 573-701, Republic of Korea \\ ${ }^{2}$ Marine Biotechnology Laboratory (MBL), School of Earth and Environmental Sciences, Seoul National University, \\ Seoul 151-747, Republic of Korea \\ ${ }^{3}$ Institute of Environmental Research, Inje University, Kimhae 621-749, Republic of Korea
}

\begin{abstract}
To investigate the interactions among a toxic dinoflagellate Amphidinium carterae, the heterotrophic dinoflagellate Oxyrrhis marina, and the calanoid copepods Acartia spp. (A. omorii and $A$. hongi), we measured toxicity of $A$. carterae, the growth and ingestion rates of $O$. marina on A. carterae, the ingestion rate of Acartia spp. on $A$. carterae, the ingestion rate of Acartia spp. on O. marina fed a non-toxic strain of Prorocentrum minimum, and the ingestion rate of Acartia spp. on $O$. marina, the latter originally satiated with $A$. carterae and then starved, as a function of elapsed starvation time. The toxicity of $A$. carterae was $1 \mathrm{MU} / 1.3 \times 10^{8}$ cells when measured using the mouse bioassay. O. marina grew well on $A$. carterae. When the data were fitted to the Michaelis-Menten equation, maximum specific growth rate $\left(\mu_{\max }\right)$ and threshold prey concentration of $O$. marina on $A$. carterae were $1.17 \mathrm{~d}^{-1}$ and $1.3 \mathrm{ng} \mathrm{C} \mathrm{ml}^{-1}\left(13 \mathrm{cells} \mathrm{ml}^{-1}\right)$, respectively. Maximum ingestion and clearance rates of $O$. marina were $2.8 \mathrm{ng} \mathrm{C}$ grazer $^{-1} \mathrm{~d}^{-1}\left(28\right.$ cells grazer $\left.{ }^{-1} \mathrm{~d}^{-1}\right)$ and $2.4 \mu \mathrm{grazer}{ }^{-1} \mathrm{~h}^{-1}$, respectively. Grazing by Acartia spp. on A. carterae was undetectable. The ingestion rate of Acartia spp. on $O$. marina was very low (maximum $=749$ Oxyrrhis predator $\left.{ }^{-1} \mathrm{~d}^{-1}\right)$ at Day $0(O$. marina starved for 0 to $1 \mathrm{~d}$ after satiation with $A$. carterae), but increased with increasing elapsed starvation time. The maximum ingestion rate was 4710 Oxyrrhis predator ${ }^{-1} \mathrm{~d}^{-1}$ at Day 11 (O. marina starved for 11 to $12 \mathrm{~d}$ ). The average ingestion rates of Acartia spp. on $O$. marina fed $P$. minimum were not significantly higher than on $O$. marina fed $A$. carterae at Day 11 at similar mean prey concentrations, but much higher than those fed $A$. carterae at Day 0. This evidence suggests that $O$. marina can reduce its mortality rate due to the predation by Acartia spp. if it is satiated with $A$. carterae, and the grazing of $A$. carterae by $O$. marina can sometimes transfer the carbon of $A$. carterae to Acartia spp., which cannot feed on A. carterae.
\end{abstract}

KEY WORDS: Ecological role $\cdot$ Growth $\cdot$ Grazing $\cdot$ Ingestion $\cdot$ Protist $\cdot$ Toxin

\section{INTRODUCTION}

Autotrophic (and/or mixotrophic) dinoflagellates, heterotrophic protists, and copepods are the major components of marine plankton communities. Grazing

*E-mail: hjjeong@kunsan.ac.kr pressure sometimes plays an important role in the population dynamics of autotrophic dinoflagellates (Watras et al. 1985). In particular, grazing by heterotrophic protists is believed to contribute to the decline of dinoflagellate blooms (Holmes 1967, Eppley \& Harrison 1975, Jeong 1995). However, there have been few studies that demonstrate effective grazing by hetero- 
trophic protists or metazooplankton on toxic dinoflagellates, and many studies indicate that most heterotrophic protists or metazooplankton do not feed on toxic dinoflagellates (Hansen 1989, Kamiyama 1997, Turner \& Tester 1997).

Toxins may play an important role in reducing grazing pressure if there are no effective grazers on a toxic dinoflagellate, and the materials of the dinoflagellate will not be transferred to higher trophic levels. However, if grazers can feed effectively on a toxic dinoflagellate and do not accumulate the toxin, the grazers may control the toxic dinoflagellate population and transfer their materials to higher trophic level organisms without harming them.

A few heterotrophic protists have been known to feed on the toxic dinoflagellate Amphidinium carterae (Blackbourn 1974, Naustvoll 1998). However, there have been no reports of the positive growth of heterotrophic protists on A. carterae. A. carterae is a bloom organism (Steidinger \& Tangen 1997) and can undergo daily vertical migrations (Kamykowski \& Zentara 1976, Steidinger \& Tangen 1997). Recently we found that the heterotrophic dinoflagellate Oxyrrhis marina was able to grow well on $A$. carterae. This strain of $A$. carterae was previously known to be poor prey for the mixotrophic dinoflagellate Fragilidium cf. mexicanum (Jeong et al. 1999a), the heterotrophic dinoflagellate Polykrikos kofoidii (Jeong et al. 2001), and the naked ciliate Strombidinopsis sp. (Jeong et al. 1999b).

The functional and numerical responses of Oxyrrhis marina to Amphidinium carterae and the functional response of a copepod to $O$. marina fed $A$. carterae are important concerns in understanding trophodynamics related to toxic dinoflagellates. Considering the high growth rate of $O$. marina on $A$. carterae, $O$. marina may be insensitive to the toxin and/or have an ability to detoxify it. If a copepod which does not feed on $A$. carterae can actively prey on $O$. marina fed on $A$. carterae, O. marina can play an important role in transferring the materials of $A$. carterae to the copepod.

To understand the interactions among Amphidinium carterae, Oxyrrhis marina, and Acartia spp., we conducted experiments to measure the toxicity of $A$. carterae using the mouse bioassay, the growth and ingestion rates of $O$. marina on $A$. carterae, the ingestion rate of Acartia spp. on $A$. carterae, the ingestion rate of Acartia spp. on $O$. marina fed a non-toxic strain of Prorocentrum minimum, and the ingestion rates of Acartia spp. on $O$. marina, originally satiated with $A$. carterae and then starved, as a function of elapsed starvation time. The results of the present study provide a basis for understanding the potential of heterotrophic dinoflagellates to influence the population dynamics of toxic dinoflagellates, and the transfer of carbon from toxic dinoflagellate to larger zooplankton, as well as the roles of heterotrophic dinoflagellates in toxin dynamics.

\section{MATERIALS AND METHODS}

Preparation of experimental organisms. Amphidinium carterae (ACKS 0010) were grown at $20^{\circ} \mathrm{C}$ in enriched f/2 seawater media (Guillard \& Ryther 1968) without silicate, with continuous illumination at $100 \mu \mathrm{E} \mathrm{m} \mathrm{m}^{-2} \mathrm{~s}^{-1}$ provided by cool white fluorescent lights. The carbon content for $A$. carterae $(0.1 \mathrm{ng} \mathrm{C}$ cell $^{-1}$ ) was measured using a CHN analyzer.

For isolation and culture of Oxyrrhis marina, plankton samples collected with a $25 \mathrm{~cm}$ diameter, $25 \mu \mathrm{m}$ mesh plankton net were taken from the mouth of Keum Estuary, Kunsan, Korea, during May 1999, when the water temperature was $16^{\circ} \mathrm{C}$. The samples were screened gently through a $154 \mu \mathrm{m}$ Nitex mesh and placed in 11 polycarbonate (PC) bottles. A mixture of Prorocentrum minimum and Amphidinium carterae (8000 cells $\mathrm{ml}^{-1}$ for each prey) and $50 \mathrm{ml}$ of $\mathrm{f} / 2$ media was added as food. Bottles were placed on plankton wheels rotating at $0.9 \mathrm{rpm}$ and incubated at $20^{\circ} \mathrm{C}$ under continuous illumination at $20 \mu \mathrm{E} \mathrm{m} \mathrm{m}^{-2} \mathrm{~s}^{-1}$ of cool white fluorescent light. Two days later, aliquots of the enriched water were transferred to 6-well tissue culture plates and a monoclonal culture was established by 2 serial single-cell isolations. Once dense cultures of $O$. marina were obtained, they were transferred to 500 or $1000 \mathrm{ml}$ PC bottles of fresh prey every 2 or $3 \mathrm{~d}$. Experiments were conducted when a large volume of O. marina culture was available.

Copepods were collected from the mouth of Keum Estuary with a $303 \mu \mathrm{m}$ mesh net, and acclimated in a $20^{\circ} \mathrm{C}$ room in the presence of Prorocentrum minimum. Acartia hongi (Soh \& Suh 2000) and A. omorii, which co-occur in coastal waters off western Korea, are very similar and are impossible to distinguish from each other when they are alive. Therefore, we had to use a mixture of adult female Acartia spp. (A. hongi and $A$. omorii).

Cell volume. Cell length and maximum width of Oxyrrhis marina preserved in 5\% acid Lugol's solution were measured with using both a compound and an inverted microscope. The shape of $O$. marina was estimated as a cone (bottom half of the cell) connected to another cone (top half of the cell). The 2 cones joined at the cell equator (= maximum width of the cell). Cell volume of the preserved $O$. marina was calculated according to the equation: volume $=1 / 3 \times$ crosssectional area at equator $\times$ cell length.

Toxicity of Amphidinium carterae. To extract toxic materials, dense cultures of Amphidinium carterae (100 l in total; 21000 cells ml $^{-1}$ or $2100 \mathrm{ng} \mathrm{C} \mathrm{ml}^{-1}$ ) were 
harvested by filtration with glass-fibred filters (Whatman GF/C). The harvested cells were extracted with $50 \%$ methanol (MeOH)/dichloromethane (DCM) followed by $100 \%$ methanol (100 ml each) at $25^{\circ} \mathrm{C}$ for $7 \mathrm{~h}$, respectively. The combined extract was concentrated under vacuum with a rotary evaporator. The residual water was completely dried under high vacuum. The crude extract thus obtained was dissolved in 50\% $\mathrm{MeOH} / \mathrm{DCM}$ under helium and kept at $-80^{\circ} \mathrm{C}$ until use. The crude extract was used for mouse assay to assess the toxicity of $A$. carterae.

The crude extract was aliquoted in $1.5 \mathrm{ml}$ sterilized Eppendorff tubes, and the solvents completely evaporated under vacuum. The aliquots were suspended in $1 \%$ Tween 60 (Aldrich) sterilized-saline solution. The solutions were sonicated for 2 min to give a homogeneous suspension of compounds. Serially diluted samples, equivalent to $0.1,0.2,0.3,0.4,0.6,0.8,1,1.2$ and 1.51 each $\left(11\right.$ corresponding to $1.6 \times 10^{8}$ cells of $A$. carterae), were prepared in the final volume of $600 \mu \mathrm{l}$. The solutions were injected intra-peritoneally into 4 wk old male mice of the ICR strain (weight range: 19 to $24 \mathrm{~g}$ each). Each solution was injected in duplicate or triplicate, depending upon the reproducibility of injection. The injected mice were observed in a verywell-controlled environment for $48 \mathrm{~h}$.

Growth and ingestion rates of Oxyrrhis marina on Amphidinium carterae. Expts 1 and 2 were designed to measure the growth, ingestion, and clearance rates of Oxyrrhis marina on Amphidinium carterae as a function of the prey concentration (Table 1). In particular, Expt 2 was designed to measure rates at low prey concentrations because the threshold prey concentration was revealed to be very low in Expt 1.

Dense cultures of Oxyrrhis marina growing on Amphidinium carterae were transferred, 2 or $3 \mathrm{~d}$ before the experiments were conducted, into $11 \mathrm{PC}$ bottles containing low concentrations of the prey (50 and 5 cells $\mathrm{ml}^{-1}$ for Expts 1 and 2, respectively). The bottles were filled to capacity with filtered seawater and placed on rotating wheels to incubate as above, except that illumination was provided on a 12:12 h light:dark cycle. To monitor the condition of and interaction between predator and prey species, cultures were periodically removed from the rotating wheels, examined by looking through the surface of capped bottles using a dissecting microscope, and then returned to the rotating wheels. Once $A$. carterae cells were no longer detectable, three $1 \mathrm{ml}$ aliquots from each bottle were counted using a compound microscope to determine cell concentrations of O. marina, and the cultures then used to conduct experiments.

For each experiment, initial concentrations of $\mathrm{Ox}_{\mathrm{x}}$ yrrhis marina and Amphidinium carterae were established using an autopipette to deliver predetermined volumes of known cell concentrations to the bottles. Triplicate $270 \mathrm{ml}$ (Expt 1) or $500 \mathrm{ml}$ (Expt 2) PC experiment bottles (mixtures of predator and prey), and triplicate control bottles (prey only) were set up for each predator-prey combination. Triplicate control bottles containing only $O$. marina were also established at 1 predator concentration. Thirty $\mathrm{ml}$ (Expt 1) or $50 \mathrm{ml}$ (Expt 2) of f/2 medium were added to all bottles, which were then filled to capacity with freshly filtered seawater and capped. To determine actual predator and prey densities at the beginning of the experiment, a $10 \mathrm{ml}$ aliquot was removed from each bottle, fixed with $5 \%$ acid Lugol's solution and examined with a compound microscope to determine predator and prey abundance by enumerating cells in three $1 \mathrm{ml}$ SedgwickRafter counting chambers (SRCs). The bottles were filled again to capacity with freshly filtered seawater, capped, and placed on rotating wheels with the environmental conditions described above. Dilution of the

Table 1. Design of experiments. The numbers in prey and predator columns are the actual initial densities (cells $\mathrm{ml}^{-1} \mathrm{for}^{\mathrm{Amphi}} \mathrm{m}$ dinium carterae and Oxyrrhis marina and ind. $\mathrm{l}^{-1}$ for Acartia spp.) of prey and predator

\begin{tabular}{|c|c|c|c|c|}
\hline \multirow[t]{2}{*}{ Expt } & \multicolumn{2}{|r|}{ Prey } & \multicolumn{2}{|c|}{ Predator } \\
\hline & Species & Density & Species & Density \\
\hline 1 & A. carterae & $0,40,71,235,727,1437,2228,9807$ & O. marina & $9,3,4,8,15,18,17,3$ \\
\hline 2 & A. carterae & $0,4,7,14,37,57,75$ & O. marina & $5,2,3,3,5,5$ \\
\hline 3 & A. carterae & $80,242,908,1765,3798,11763$ & Acartia spp. & 12 \\
\hline 4 & O. $\operatorname{marina}^{\mathrm{a}}$ & $44,90,323,410,675,1540$ & Acartia spp. & 20 \\
\hline 5 & O. marina $^{\mathrm{b}}$ & $27,66,139,252,527,1266$ & Acartia spp. & 20 \\
\hline 6 & O. marina ${ }^{\mathrm{b}}$ & 522,1333 & Acartia spp. & 20 \\
\hline 7 & O. marina ${ }^{b}$ & 526,992 & Acartia spp. & 2 \\
\hline 8 & O. marina ${ }^{\mathrm{b}}$ & $22,47,102,209,573,923$ & Acartia spp. & 2 \\
\hline
\end{tabular}


cultures associated with refilling the bottles was considered in calculating growth and ingestion rates.

Aliquots of $10 \mathrm{ml}$ (Expt 1) or $20 \mathrm{ml}$ (Expt 2) were taken from each bottle at 24,48 , and $72 \mathrm{~h}$, fixed with $5 \%$ Lugol's solution and the abundances of Oxyrrhis marina and Amphidinium carterae were determined by counting all or $>300$ cells in three $1 \mathrm{ml}$ SRCs. In Expt $210 \mathrm{ml}$ aliquots were transferred into wells of a 6well plate chamber, the chamber was gently rotated by hand to concentrate most cells near the center of the chamber, and then the cells were counted using an inverted microscope. Prior to taking subsamples, the condition of $O$. marina and its prey was assessed using a dissecting microscope as described above. After subsampling, bottles were again filled to capacity with freshly filtered seawater and placed back on the rotating wheels.

The specific growth rate of Oxyrrhis marina, $\mu\left(\mathrm{d}^{-1}\right)$, was calculated by averaging the instantaneous growth rates (IGRs) for each sampling interval:

$$
\mathrm{IGR}=\frac{\ln \left(S_{t_{2}} / S_{t_{1}}\right)}{t_{2}-t_{1}} \times 24
$$

where $S_{t_{1}}$ and $S_{t_{2}}=$ the concentration of $O$. marina at consecutive samplings. The final $t_{2}$ for calculation was $48 \mathrm{~h}$, which provided the highest specific growth rate.

Data for Oxyrrhis marina growth rates were fitted to a Michaelis-Menten equation:

$$
\mu=\frac{\mu_{\max }\left(x-x^{\prime}\right)}{K_{\mathrm{GR}}+\left(x-x^{\prime}\right)}
$$

where $\mu_{\max }=$ the maximum growth rate $\left(\mathrm{d}^{-1}\right) ; x=$ prey concentration (cells ml ${ }^{-1}$ or $\mathrm{ng} \mathrm{C} \mathrm{ml}^{-1}$ ), $x^{\prime}=$ threshold prey concentration (the prey concentration where $\mu=$ $0), K_{\mathrm{GR}}=$ the prey concentration sustaining $1 / 2 \mu_{\max }$. Data were iteratively fitted to the model using DeltaGraph $^{\circledast}$ (Delta Point).

Ingestion and clearance rates were calculated using the equations of Frost (1972) and Heinbokel (1978). Incubation time for calculating ingestion and clearance rates was the same as for estimating growth rate. Ingestion rate data were fitted to a Michaelis-Menten equation:

$$
\mathrm{IR}=\frac{I_{\max }(x)}{K_{\mathrm{IR}}+(x)}
$$

where $I_{\max }=$ the maximum ingestion rate (cells grazer $^{-1} \mathrm{~d}^{-1}$ or ng $\mathrm{C}$ grazer $\left.{ }^{-1} \mathrm{~d}^{-1}\right) ; x=$ prey concentration (cells $\mathrm{ml}^{-1}$ or ng C ml${ }^{-1}$ ), $K_{\mathrm{IR}}=$ the prey concentration sustaining $1 / 2 I_{\max }$.

Ingestion rates of Acartia spp. on Amphidinium carterae. Expt 3 was designed to measure the ingestion and clearance rates of Acartia spp. on Amphidinium carterae as a function of the prey concentration
(Table 1). Adult female Acartia spp. (a mixture of $A$. omorii and A. hongi) were used.

For the experiment, initial concentrations of Amphidinium carterae were established using an autopipette to deliver predetermined volumes of known cell concentrations to the bottles, and those of Acartia spp. were obtained by individually transferring the copepods using a Pasteur pipette. Triplicate $500 \mathrm{ml}$ PC experiment bottles (mixtures of predator and prey) and triplicate control bottles (prey only) were set up for each predator-prey combination. Fifty $\mathrm{ml}$ of $\mathrm{f} / 2$ medium were added to all bottles, which were then filled to capacity with freshly filtered seawater and capped. To determine actual prey densities at the beginning of the experiment, a $10 \mathrm{ml}$ aliquot was removed from each bottle, fixed with $5 \%$ Lugol's solution and examined with a compound microscope to determine prey abundance by enumerating cells in three $1 \mathrm{ml}$ SRCs. The bottles were filled again to capacity with freshly filtered seawater, capped, and placed on plankton wheels rotating at $0.9 \mathrm{rpm}$ and incubated at $20^{\circ} \mathrm{C}$ under an illumination of $20 \mu \mathrm{E} \mathrm{m}^{-2} \mathrm{~s}^{-1}$ in a $12: 12 \mathrm{~h}$ light:dark cycle.

Aliquots of $10 \mathrm{ml}$ were taken from each bottle at 24 and $48 \mathrm{~h}$ and fixed with $5 \%$ Lugol's solution; the abundances of Amphidinium carterae were determined by counting all or $>300$ cells in three $1 \mathrm{ml} \mathrm{SRCs.} \mathrm{After} \mathrm{sub-}$ sampling, bottles were again filled to capacity with freshly filtered seawater and placed back on the rotating wheels. After incubation for $48 \mathrm{~h}$, Acartia spp. were counted. Mortality of Acartia spp. was nil at the end of incubation.

Ingestion and clearance rates were calculated using the equations of Frost (1972).

Ingestion rates of Acartia spp. on Oxyrrhis marina fed Prorocentrum minimum. Expt 4 was designed to investigate the ingestion rates of Acartia spp. on Oxyrrhis marina which had been grown with a nontoxic strain of Prorocentrum minimum as food (Table 1). Adult female Acartia spp. (A. omorii and A. hongi) were used for this experiment.

Dense cultures (ca 1100 cells $\mathrm{ml}^{-1}$ ) of Oxyrrhis marina growing on Prorocentrum minimum were transferred into $21 \mathrm{PC}$ bottles containing cultures of P. minimum (ca 12000 cells ml$^{-1}$ ). For 24 h, O. marina actively eliminated $P$. minimum cells, and the concentration of $P$. minimum decreased to an undetectable concentration. The density of the predator increased to 2030 cells ml ${ }^{-1}$.

For this experiment, initial concentrations of Oxyrrhis marina and Acartia spp. were established as described above. Triplicate $500 \mathrm{ml}$ PC experiment bottles and triplicate control bottles were set up for each predatorprey combination. All bottles were filled to capacity with freshly filtered seawater and capped. Actual prey 
densities at the beginning of the experiment were determined as described above. The bottles were filled again to capacity with freshly filtered seawater, capped, and placed on rotating wheels using the environmental conditions described in the last sub-section.

Aliquots of $10 \mathrm{ml}$ were taken from each bottle at 24 and $48 \mathrm{~h}$ and fixed with $5 \%$ Lugol's solution; the abundances of Oxyrrhis marina were determined by counting all or > 200 cells in three $1 \mathrm{ml}$ SRCs. After subsampling, bottles were again filled to capacity with freshly filtered seawater and placed back on the rotating wheels. After incubation, Acartia spp. were counted.

Ingestion and clearance rates were calculated using the equations of Frost (1972).

Ingestion rates of Acartia spp. on Oxyrrhis marina fed Amphidinium carterae. Expts 5 to 8 were designed to investigate the ingestion rates of Acartia spp. on Oxyrrhis marina which had been grown with Amphidinium carterae as food and then starved (Table 1). Adult female Acartia spp. (A. omorii and A. hongi) were used for these experiments.

Dense cultures (mean $\pm \mathrm{SE}=848 \pm 50$ cells ml $^{-1}$ ) of Oxyrrhis marina were starved for $2 \mathrm{~d}$ and then transferred into four $220 \mathrm{l}$ tanks containing cultures of Amphidinium carterae (mean $\pm \mathrm{SE}=10953 \pm 923$ cells $\mathrm{ml}^{-1}$ ). In the first $20 \mathrm{~h}, O$. marina eliminated the $A$. carterae cells and the concentration of Amphidinium carterae decreased to approximately 40 cell ml-1. Most O. marina cells were observed to contain 6 to 7 ingested $A$. carterae cells at this time. To avoid the interference of remaining $A$. carterae, the $O$. marina culture was held for $20 \mathrm{~h}$ until there were no free $A$. carterae cells remaining. The densities of $O$. marina increased to $1402 \pm 23$ cells ml $^{-1}$, and most $O$. marina cells were observed to contain none or 1 ingested $A$. carterae cells when the first feeding trial with copepods was begun. Therefore, most O. marina cells had been starved for $20 \mathrm{~h}$ when they were first fed to copepods. Days 0 (Expt 5), 3 (Expt 6), 8 (Expt 7), and 11 (Expt 8) indicate the number of days after Expt 5 started (see Table 1). At Days 0, 3, 8, and 11, 21 aliquots were taken from each tank and of these, $3 \mathrm{ml}$ aliquots were counted to determine the $O$. marina density in each tank. Cell size was measured. The remaining aliquots were mixed (and slightly concentrated using a $5 \mu \mathrm{m}$ mesh net if necessary) and counted again.

For each experiment, initial concentrations of Oxyrrhis marina and Acartia spp. were established as described above. Triplicate $500 \mathrm{ml}$ PC experiment bottles and triplicate control bottles were set up for each predator-prey combination. All bottles were filled to capacity with freshly filtered seawater and capped. Actual prey densities at the beginning of the experiment were determined as described above. The bottles were filled again to capacity with freshly filtered sea- water, capped, and placed on rotating wheels using the environmental conditions described above.

Aliquots of $10 \mathrm{ml}$ were taken from each bottle at 24 and $48 \mathrm{~h}$, fixed with $5 \%$ acid Lugol's solution; the abundances of Oxyrrhis marina were determined as described in the last sub-section. After subsampling, bottles were again filled to capacity with freshly filtered seawater and placed back on the rotating wheels. After incubation, Acartia spp. were counted.

Ingestion and clearance rates were calculated using the equations of Frost (1972).

\section{RESULTS}

Toxicity of Amphidinium carterae. The minimum lethal dose of Amphidinium carterae to mice was the crude whole-cell extract representing toxin present in $1.3 \times 10^{8}$ cells $\left(1.3 \times 10^{7} \mathrm{ng} \mathrm{C}\right)$. The first symptom of toxicity to mice was prostration. Both hind limbs were paralyzed a few minutes later (usually in $2 \mathrm{~min}$ ). The paralyzed mice experienced severe dyspnea and a violent paroxysm before death.

Growth rate of Oxyrrhis marina fed Amphidinium carterae (Expts 1 and 2). Oxyrrhis marina grew well on unialgal diets of Amphidinium carterae. The specific growth rates increased with increasing mean prey concentration up to ca $100 \mathrm{ng} \mathrm{C} \mathrm{ml}^{-1}$, but were saturated at higher prey concentrations (Fig. 1). When the data were fitted to Eq. (2), the maximum specific growth

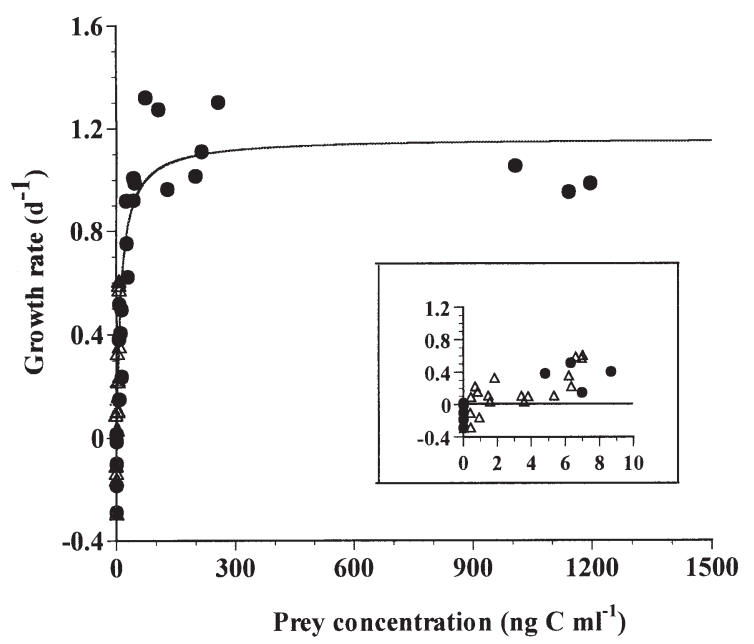

Fig. 1. Specific growth rates of Oxyrrhis marina on Amphidinium carterae as a function of mean prey concentration $(x)$. Symbols represent single treatments. The equation of the regression line was obtained by pooling all treatments from Expts $1(\bullet)$ and $2(\Delta)$. The curves are fitted by a MichaelisMenten equation (Eq. 2) using all treatments in the experiment. Growth rate $\left(\mathrm{GR}, \mathrm{d}^{-1}\right)=1.17\{(x-1.3) /[12.5+(x-1.3)]\}$, $\mathrm{R}^{2}=0.923$. Inset shows values at low prey concentrations 
rates $\left(\mu_{\mathrm{max}}\right)$ and $K_{\mathrm{GR}}$ (prey concentration sustaining $\left.0.5 \mu_{\text {max }}\right)$ were $1.17 \mathrm{~d}^{-1}$ and $12 \mathrm{ng} \mathrm{C} \mathrm{ml} \mathrm{C}^{-1}$ (120 cells $\mathrm{ml}^{-1}$ ), respectively. The threshold prey concentration (where net growth $=0$ ) was $1.3 \mathrm{ng} \mathrm{C} \mathrm{ml}{ }^{-1}$ (13 cells $\mathrm{ml}^{-1}$ ). The result from Expt 2 confirmed this very low threshold prey concentration.

Ingestion and clearance rates of Oxyrrhis marina on Amphidinium carterae (Expts 1 and 2). The ingestion rate of Oxyrrhis marina on unialgal diets of

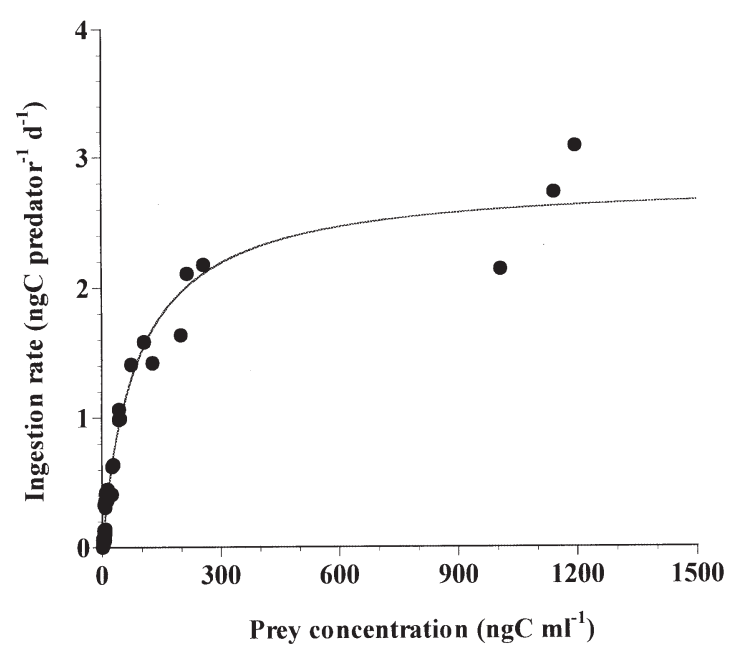

Fig. 2. Ingestion rates of Oxyrrhis marina on Amphidinium carterae as a function of mean prey concentration $(x)$. Symbols represent single treatments. The equation of the regression line was obtained by pooling all treatments from Expts 1 and 2. The curves are fitted by a Michaelis-Menten equation (Eq. 3) using all treatments in the experiment. Ingestion rate $\left(\mathrm{IR}, \mathrm{ng} \mathrm{C}\right.$ predator $\left.{ }^{-1} \mathrm{~d}^{-1}\right)=2.8[\mathrm{x} /(90+x)], \mathrm{R}^{2}=0.97$

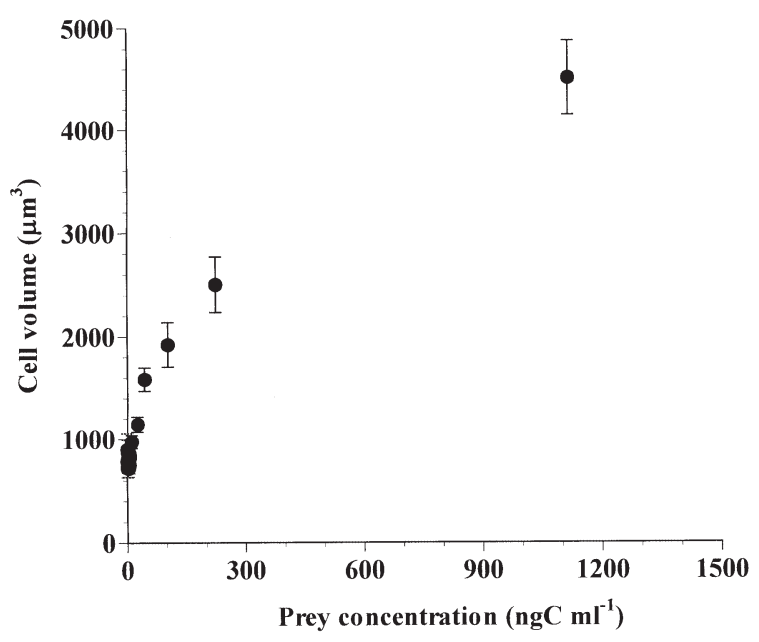

Fig. 3. Cell volume of Oxyrrhis marina on Amphidinium carterae as a function of mean prey concentration in Expts 1 and 2 (see Table 1). Symbols represent treatment means $\pm 1 \mathrm{SE}$
Amphidinium carterae increased rapidly with increasing mean prey concentration up to ca $200 \mathrm{ng} \mathrm{C} \mathrm{ml}^{-1}$ (2000 cells $\mathrm{ml}^{-1}$ ), and slowly, but continuously, increased at higher prey concentrations (Fig. 2). When the data were fitted to Eq. (2), the maximum ingestion rate and $K_{\text {IR }}$ (prey concentration sustaining $0.5 I_{\max }$ ) of $O$. marina on $A$. carterae were $2.8 \mathrm{ng} \mathrm{C}$ grazer $^{-1} \mathrm{~d}^{-1}$ (28 cells grazer ${ }^{-1} \mathrm{~d}^{-1}$ ) and $90 \mathrm{ng} \mathrm{C} \mathrm{ml} \mathrm{C}^{-1}\left(900 \mathrm{cells} \mathrm{ml}^{-1}\right.$ ), respectively.

The maximum clearance rate of Oxyrrhis marina was $2.4 \mu$ grazer $^{-1} \mathrm{~h}^{-1}$.

Cell volume of Oxyrrhis marina fed Amphidinium carterae in Expts 1 and 2 and $O$. marina fed Prorocentrum minimum in Expt 4. In general the cell volume of Oxyrrhis marina fed Amphidinium carterae did not change markedly with increasing prey concentration $\leq 7 \mathrm{ng} \mathrm{C} \mathrm{ml}^{-1}$ (700 to $900 \mu^{3}$ ) but cell volume increased at higher prey concentrations and reached a maximum of $4500 \mu^{3}$ at the prey concentration of $1114 \mathrm{ng} \mathrm{C} \mathrm{ml} \mathrm{C}^{-1}$ (11 140 cells $\mathrm{ml}^{-1}$ ) (Fig. 3). O. marina appeared to ingest as many prey cells as possible, with 10 Amphidinium carterae cells occurring in the protoplasm of some specimens. Accumulation of prey in $O$. marina caused an increase in the length and width.

Cell volume of Oxyrrhis marina fed Prorocentrum minimum in Expt 4 was $3018 \mu^{3}$.

Ingestion rate of Acartia spp. on Amphidinium carterae (Expt 3). In our experiments, grazing by Acartia spp. on $A$. carterae was undetectable.

Ingestion rates of Acartia spp. on Oxyrrhis marina fed Prorocentrum minimum (Expt 4). The ingestion rates of Acartia spp. on Oxyrrhis marina grown on Prorocentrum minimum increased rapidly with increasing mean prey concentration (Fig. 4). When the data were fitted to Eq. (2), the maximum ingestion rate and $K_{\mathrm{IR}}$ of Acartia spp. on $O$. marina fed $P$. minimum were 22500 cells predator ${ }^{-1} \mathrm{~d}^{-1}$ and 1800 cells $\mathrm{ml}^{-1}$, respectively.

Ingestion rates of Acartia spp. on Oxyrrhis marina fed Amphidinium carterae (Expts 5 to 8). The ingestion rates of Acartia spp. on Oxyrrhis marina grown on Amphidinium carterae and then starved were affected by elapsed starvation time of $O$. marina. When the initial prey concentrations were 522 to 573 O. marina cells $\mathrm{ml}^{-1}$, the ingestion rates of Acartia sp. on $O$. marina at Day 0 (O. marina starved for $0-1 \mathrm{~d}$ after satiation with A. carterae) and Day 3 (3 to 4 d after satiation) were 0 , but increased with increasing elapsed starvation time and reached a maximum of 2275 Oxyrrhis predator ${ }^{-1}$ $\mathrm{d}^{-1}$ at Day 11 (Fig. 5). When the initial prey concentrations were 923 to 1333 cells $\mathrm{ml}^{-1}$, the ingestion rate of Acartia sp. on O. marina at Day 0 was 426 Oxyrrhis predator $^{-1} \mathrm{~d}^{-1}$, but increased with increasing elapsed starvation time and reached the maximum ingestion rate of 4710 O. marina predator ${ }^{-1} \mathrm{~d}^{-1}$ at Day 11 . 


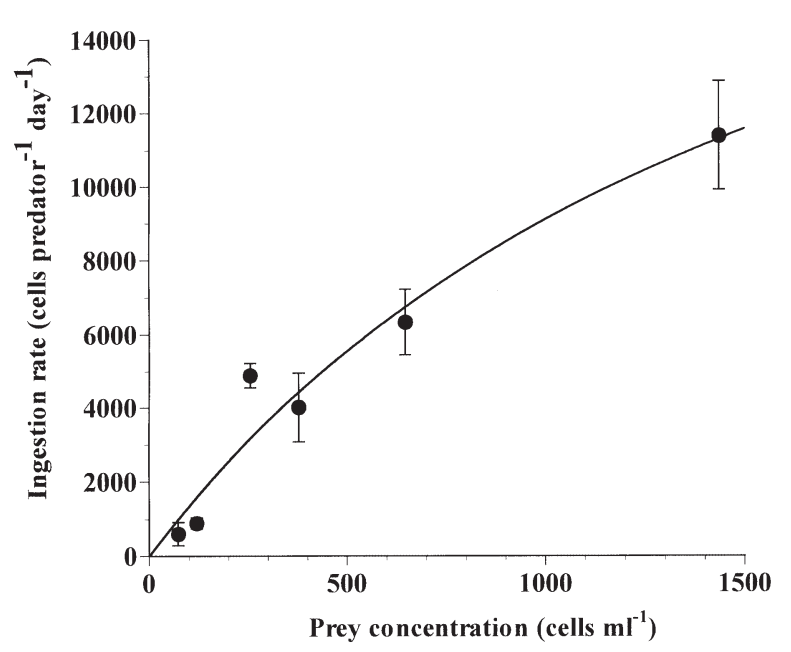

Fig. 4. Ingestion rates of Acartia spp. (A. omorii and A. hongi) on Oxyrrhis marina satiated with a non-toxic strain of Prorocentrum minimum as a function of mean Oxyrrhis concentration $(x)$. Symbols represent treatment means \pm 1 SE The curve is fitted as in Fig. 2. Ingestion rate (IR, cells predator ${ }^{-1} \mathrm{~d}^{-1}$ ) $=25500[x /(1800+x)], R^{2}=0.859$

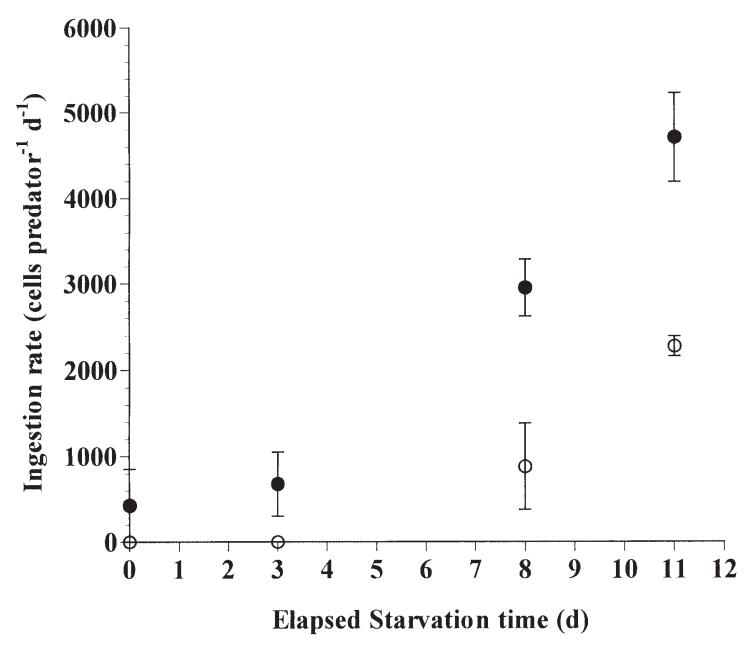

Fig. 5. Ingestion rates of Acartia spp. (A. omorii and A. hongi) on Oxyrrhis marina satiated with Amphidinium carterae and then starved as a function of elapsed starvation time in Expts 5 to 8 (see Table 1) when the initial prey concentrations were 522 to 573 (०) and 923 to 1333 cells $\mathrm{ml}^{-1}(\bullet)$. Symbols represent treatment means $\pm 1 \mathrm{SE}$

The functional response of Acartia spp. to Oxyrrhis marina which had been grown on Amphidinium carterae was also affected by starvation time of the $O$. marina. At Day 11 the ingestion rates increased with increasing $O$. marina density, but at Day 0 there was no consistent trend with the maximum ingestion rate of 749 Oxyrrhis predator ${ }^{-1} \mathrm{~d}^{-1}$ at a mean prey concentration of 252 cells ml $\mathrm{m}^{-1}$ (Fig. 6). The ingestion rates of

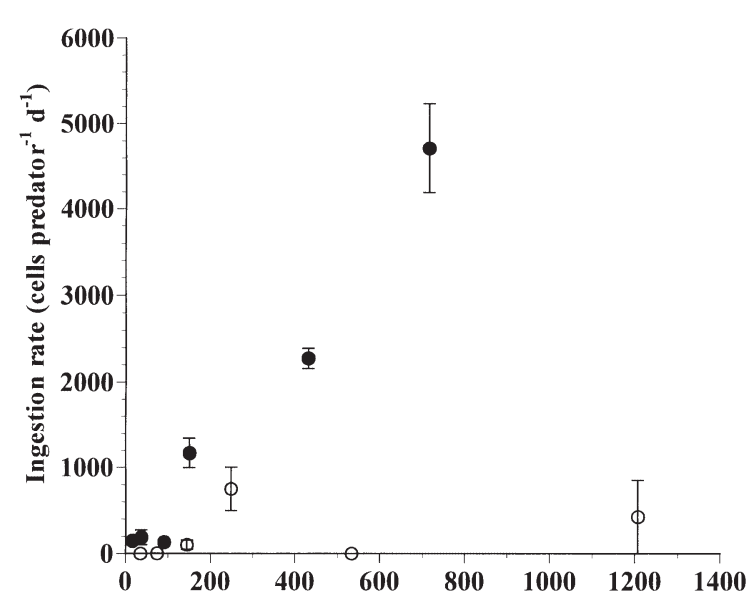

Prey concentration (cells $\mathrm{ml}^{-1}$ )

Fig. 6. Ingestion rates of Acartia spp. (A. omorii and A. hongi) on Oxyrrhis marina satiated with Amphidinium carterae and then starved at Day $0(0)$ and Day $11(\bullet)$ as a function of the $O$. marina concentration in Expts 5 to 8 (see Table 1). Symbols represent treatment means $\pm 1 \mathrm{SE}$

Acartia spp. on Oxyrrhis marina fed A. carterae at the mean prey concentrations of 431 and 716 Oxyrrhis $\mathrm{ml}^{-1}$ at Day 11 were not significantly lower than those which had been fed Prorocentrum minimum at 377 and 647 Oxyrrhis $\mathrm{ml}^{-1}$, respectively $(0.1>\mathrm{p}>0.05$ for both, 1-tailed $t$-test; Zar 1984). At Day 0 the ingestion rates of copepods for $O$. marina fed $A$. carterae were much lower than those for $O$. marina fed $P$. minimum at all $O$. marina concentrations. These differences do not appear to be due to cell size: at Day 0 O. marina fed $P$. minimum were larger $\left(3.0 \times 10^{3} \mu^{3}\right)$ than $O$. marina fed $A$. carterae $\left(2.0 \times 10^{3}{\mu \mathrm{m}^{3}}^{3}\right)$. However, $O$. marina fed $A$. carterae declined in size by Day 11 $\left(1.1 \times 10^{3} \mu^{3}\right)$.

Cell density and cell volume of Oxyrrhis marina on Amphidinium carterae in Expts 5 to 8. The cell densities of Oxyrrhis marina satiated with Amphidinium carterae and then starved slightly increased from 1405 cells ml $\mathrm{m}^{-1}$ at Day 0 to 1493 cells $\mathrm{ml}^{-1}$ at Day 3, but decreased to 863 cells $\mathrm{ml}^{-1}$ at Day 11 (Fig. 7). That is, more than $60 \%$ of Oxyrrhis marina were able to survive after an $11 \mathrm{~d}$ starvation. Three additional experiments ascertained this resistance to long starvation.

The cell volume of Oxyrrhis marina decreased rapidly from $2045 \mu^{3}$ at Day 0 to $1624 \mu^{3}$ at Day 2, and then gradually decreased down to $1126 \mu^{3}$ at Day 11 (Fig. 8). Since O. marina had been starved for $20 \mathrm{~h}$ before being first fed to copepods (see 'Materials and methods'), their cell volume at Day 0 was smaller than their maximum volume when satiated with $A$. carterae (see Fig. 3). 


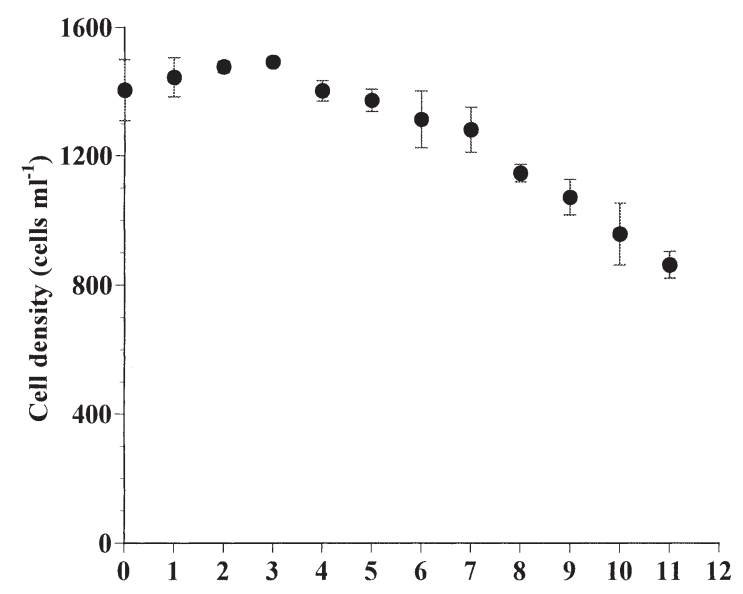

Elapsed Starvation time (d)

Fig. 7. Cell density (cells $\mathrm{ml}^{-1}$ ) of Oxyrrhis marina satiated with Amphidinium carterae and then starved as a function of elapsed starvation time in Expts 5 to 8 (see Table 1). Symbols represent treatment means $\pm 1 \mathrm{SE}$

\section{DISCUSSION}

\section{Toxicity of Amphidinium carterae}

The strain of Amphidinium carterae used in this study was toxic, although all strains of this dinoflagellate are not of equal toxicity. The toxicity of Amphidinium carterae (1 MU/1.3 × $10^{8}$ cells) was lower than that obtained in Nakajima et al. (1981) (4.7 MU/10 ${ }^{8}$ cells). The exact nature of the toxin produced by the dinoflagellate is not completely known (Ikawa \& Sasner 1975, Sasner 1975, Yasumoto 1990, Fessard et al. 1994, Nayak et al. 1997).

\section{Growth rate of Oxyrrhis marina on Amphidinium carterae}

The growth rate of the mixotrophic dinoflagellate Fragilidium cf. mexicanum (Jeong et al. 1999a), a naked ciliate Strombidinopsis sp. (Jeong et al. 1999b), and the heterotrophic dinoflagellate Polykrikos kofoidii (Jeong et al. 2001) on the same Amphidinium carterae strain used in this study was 0 or very low. The tintinnid ciliate Favella ehrenbergii (Stoecker et al. 1981) did not feed on A. carterae either. The heterotrophic dinoflagellates $D i$ plopsalis lenticula (Naustvoll 1998) and a tintinnid ciliate Favella serrata (Blackbourn 1974) are known to feed on

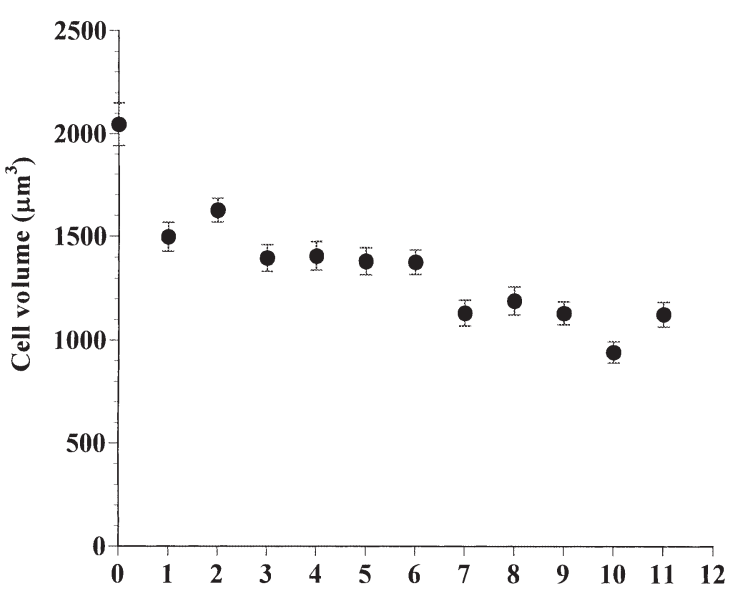

Elapsed Starvation time (d)

Fig. 8. Cell volume $\left(\mu^{3}\right)$ of Oxyrrhis marina satiated with Amphidinium carterae and then starved as a function of elapsed starvation time in Expts 5 to 8 (see Table 1). Symbols represent treatment means $\pm 1 \mathrm{SE}$

A. Carterae. However, these studies did not report positive growth of the grazers on $A$. carterae. Therefore, $O$. marina is the only protistan grazer so far reported to grow well on A. carterae.

The maximum growth rate $(\mu)$ of Oxyrrhis marina on Amphidinium carterae $\left(1.17 \mathrm{~d}^{-1}\right)$ is slightly lower than that of $O$. marina on Phaeodactylum tricornutum $\left(1.3 \mathrm{~d}^{-1}\right)$, the optimal prey so far reported, but higher than those on Dunaliella tertiolecta or Isochrysis galbana (Table 2). Therefore, A. carterae is an excellent prey for $O$. marina. This evidence suggests that $O$. marina may be insensitive to the toxin produced by A. carterae.

\section{Ingestion and clearance of Oxyrrhis marina and Acartia spp. on Amphidinium carterae}

The maximum ingestion rate $\left(2.8 \mathrm{ng} \mathrm{C}\right.$ predator $^{-1}$ $\mathrm{d}^{-1}$ ) of Oxyrrhis marina on Amphidinium carterae obtained in this study is similar to that of $O$. marina on
Table 2. Comparison of growth, ingestion, and clearance rates of Oxyrrhis marina on the different phytoplankton species at $20^{\circ} \mathrm{C} . \mu_{\max }$ : maximum growth rate as $\mathrm{d}^{-1} ; I_{\max }$ : maximum ingestion rate in $\mathrm{ng} \mathrm{C}$ predator ${ }^{-1} \mathrm{~d}^{-1} ; C_{\max }$ : maximum clearance rate as $\mu \mathrm{l}$ predator $^{-1} \mathrm{~h}^{-1}$

\begin{tabular}{|lcccl|}
\hline Prey species & $\mu_{\max }$ & $I_{\max }$ & $C_{\max }$ & \multicolumn{1}{c|}{ Source } \\
\hline Amphidinium carterae & 1.17 & 2.8 & 2.4 & This study \\
Phaeodactylum tricornutum & 1.30 & 2.6 & 0.05 & Goldman et al. (1989) \\
Dunaliella tertiolecta & 0.79 & & 0.34 & Goldman et al. (1989) \\
Isochrysis galbana & 0.79 & 7 & 0.36 & Goldman et al. (1989) \\
& & & & \\
\hline
\end{tabular}


Phaeodactylum tricornutum (2.6 ng C predator $\left.{ }^{-1} \mathrm{~d}^{-1}\right)$, but the maximum clearance rate $\left(2.4 \mu \mathrm{l}\right.$ predator $\left.{ }^{-1} \mathrm{~h}^{-1}\right)$ on the former prey is much higher than that for the latter prey (Table 2). Therefore, $O$. marina might capture and ingest $A$. carterae more efficiently than $P$. tricornutum at low prey concentrations.

In general, ingestion rates of Oxyrrhis marina increased continuously up to and beyond prey concentrations where growth rates were saturated (see Figs 1 \& 2; $K_{\mathrm{IR}}$ was higher than $K_{\mathrm{GR}}$ ). The cell volume of $O$. marina also showed a similar increase relative to prey density (Fig. 3). O. marina appeared to ingest as many prey cells as possible when prey was plentiful, raising the possibility that rapid ingestion coupled with slow digestion/assimilation of prey may have contributed to observed patterns in cell volume, as for Strombidinopsis sp. (Jeong et al. 1999b).

Feeding by Acartia spp. (A. omorii and A. hongi) on Amphidinium carterae was undetectable. Huntley et al. (1987) observed that when A. carterae was provided as food, the survival of the nauplii of the calanoid copepod Calanus pacificus declined abruptly after they reached the first feeding stages (Nauplius III). However, Houde \& Roman (1987) found that Acartia tonsa fed on a strain of $A$. carterae. These conflicting results may be due to differences in toxicity among the strains of this dinoflagellate.

\section{Ingestion rates of Acartia spp. on Oxyrrhis marina fed Amphidinium carterae and Prorocentrum minimum}

The results from Expts 4 to 8 suggest that the food quality of Oxyrrhis marina for Acartia spp. is affected by $O$. marina's prey type and elapsed starvation time. It is not uncommon for food quality of prey to be affected by the prey's diet (Rainuzzo et al. 1989). For example, the egg production of Acartia tonsa on $O$. marina is affected by the prey species used to culture O. marina (Kleppel \& Burkart 1994). However, recovery of ingestion rates of $O$. marina fed $A$. carterae after 11 to $12 \mathrm{~d}$ starvation implies that the grazer may have an ability to detoxify the toxin produced by Amphidinium carterae and/or excrete the toxin into the ambient water. For further understanding it is worth exploring the structure of the toxin produced by $A$. carterae and the mechanism of reduction of the toxic effect by $O$. marina in the bio-chemical aspects.

\section{Ecological importance}

The interactions revealed in the present study may be important in marine ecosystems in the following ways: (1) Oxyrrhis marina is an effective grazer on a toxic strain of Amphidinium carterae. (2) The mortality of $O$. marina due to predation by Acartia spp. (A. omorii and $A$. hongi) is reduced if $O$. marina has fed on A. carterae, compared to being fed Prorocentrum minimum. However, ingestion rates of Acartia spp. on $O$. marina can be restored if $O$. marina starved after eating A. carterae. (3) O. marina can transfer the materials of A. carterae to Acartia spp., which cannot feed on A. carterae. These interactions may influence our conventional view of food webs in marine planktonic community (Jeong 1999). To further understand marine plankton food webs related to toxic dinoflagellates, it would be worthwhile to investigate the interactions among other toxic dinoflagellates, heterotrophic protists, and copepods.

Acknowledgements. We are grateful to Drs Michael Mullin and Peter Franks for comments on the manuscript and to Seong Taek Kim, Young Do Yoo and Yoon Jeong Choi for technical assistance. This paper was funded by grants from a Brain Korea 21 Project (1999) in the Ministry of Education, the RRC program of MOST and KOSEF (SERC), MOMAF and KMI, and KOSEF (1999-1-13500-001-5).

\section{LITERATURE CITED}

Blackbourn DJ (1974) The feeding biology of tintinnid protozoa and some other inshore microzooplankton. PhD thesis, University of British Columbia, Vancouver

Eppley RW, Harrison WG (1975) Physiological ecology of Gonyaulax polyedra, a red tide water dinoflagellate of southern California. In: Locicero VR (ed) Proceedings of the first international conference on toxic dinoflagellate blooms. Massachusetts Science and Technology Foundation, Wakefield, p 11-22

Fessard V, Diogene G, Dubrreuil A, Quod JP, Durand-Clement M, Legay C, Puiseux-Dao S (1994) Selection of cytotoxic responses to maiotoxin and okadaic and evaluation of toxicity of dinoflagellate extracts. Nat Toxins 2:322-328

Frost BW (1972) Effects of size and concentration of food particles on the feeding behavior of the marine planktonic copepod Calanus pacificus. Limnol Oceanogr 17:805-815

Goldman JC, Dennett MR, Gordin H (1989) Dynamics of herbivorous grazing by the heterotrophic dinoflagellate Oxyrrhis marina. J Plankton Res 11:391-407

Guillard RRL, Ryther JH (1962) Studies of marine planktonic diatoms. I. Cyclotella nana Hustedt and Detonula confervacea (Cleve) Grun. Can J Microbiol 8:229-239

Hansen PJ (1989) The red tide dinoflagellate Alexandrium tamarense: effects on behaviour and growth of a tintinnid ciliate. Mar Ecol Prog Ser 53:105-116

Heinbokel JF (1978) Studies on the functional role of tintinnids in the Southern California Bight. I. Grazing and growth rates in laboratory cultures. Mar Biol 47:177-189

Holmes RW, Williams PM, Eppley RW (1967) Red water in La Jolla Bay, 1964-1966. Limnol Oceanogr 12:503-512

Houde SEL, Roman MR (1987) Effects of food quality on the functional ingestion response of the copepod Acartia tonsa. Mar Ecol Prog Ser 40:69-77

Huntley ME, Climiniello P, Lopez MDG (1987) Importance of 
food quality in determining development and survival of Calanus pacificus (Copepoda: Calanoida). Mar Biol 95: 103-113

Ikawa M, Sasner JJ (1975) Chemical and physiological studies on the marine dinoflagellate Amphidinium carterae. In: Locicero VR (ed) Proceedings of the first international conference on toxic dinoflagellate blooms. Massachusetts Science and Technology Foundation, Wakefield, p 323-332

Jeong HJ (1995) The interactions between microzooplanktonic grazers and dinoflagellates causing red tides in the open coastal waters off southern California. PhD thesis, University of California, San Diego

Jeong HJ (1999) The ecological roles of heterotrophic dinoflagellates in marine planktonic community. J Eukaryot Microbiol 46:390-396

Jeong HJ, Shim JH, Kim JS, Park JY, Lee CW, Lee Y (1999a) The feeding by the thecate mixotrophic dinoflagellate Fragilidium cf. mexicanum on red tide and toxic dinoflagellate. Mar Ecol Prog Ser 176:263-277

Jeong HJ, Shim JH, Lee CW, Kim JS, Koh SM (1999b) Growth and grazing rates of the marine planktonic ciliate Strombidinopsis sp. on red-tide and toxic dinoflagellate. J Eukaryot Microbiol 46:69-76

Jeong HJ, Kim SK, Kim JS, Kim ST, You YD, Yoon JY (2001) Growth and grazing rates of the heterotrophic dinoflagellate Polykrikos kofoidii on red-tide and toxic dinoflagellates. J Eukaryot Microbiol 48:298-308

Kamiyama T, Arima S (1997) Lethal effect of the dinoflagellate Heterocapsa circularisquama upon the tintinnid ciliate Favella taraikaensis. Mar Ecol Prog Ser 160:27-33

Kamykowski D, Zentara SJ (1977) The diurnal vertical migration of motile phytoplankton through temperature gradients. Limnol Oceanogr 22:148-151

Kleppel GS, Burkart CA (1994) Egg production and the nutritional environment of Acartia tonsa: the role of food quality in copepod nutrition. In: Harris R (ed) Zooplankton production. Proceedings of a symposium held in Plymouth, England, 15-19 August, 1994. Academi Press, London, p 297-304

Editorial responsibility: Diane Stoecker (Contributing Editor), Cambridge, Maryland, USA
Nakajima I, Oshima Y, Yasumoto T (1981) Toxicity of benthic dinoflagellates in Okinawa. Bull Jpn Soc Sci Fish 47: 1029-1033

Naustvoll LJ (1998) Growth and grazing by the thecate heterotrophic dinoflagellate Diplopsalis lenticula (Diplopsalidaceae). Phycologia 37:1-9

Nayak BB, Karunasagar I, Karunasagar I (1997) Influence of bacteria on growth and hemolysin production by marine dinoflagellate Amphidinium carterae. Mar Biol 130:35-39

Rainuzzo JR, Olsen Y, Rosenlund G (1989) The effect of enrichment diets on the fatty acid composition of the rotifer Brachionus plicatilis. Aquaculture 79:157-161

Sasner JJ (1975) Comparative studies on toxins of microorganisms. In: Locicero VR (ed) Proceedings of the first international conference on toxic dinoflagellate blooms. Massachusetts Science and Technology Foundation, Wakefield, p 433-442

Soh HY, Suh HL (2000) A new species of Acartia (Copepoda, Calanoida) from the Yellow Sea. J Plankton Res 22: 321-337

Steidinger KA, Tangen K (1997) Dinoflagellates. In: Tomas $\mathrm{CR}$ (ed) Identifying marine diatom and dinoflagellates. Academic Press, San Diego, p 387-584

Stoecker DK, Guillard RRL, Kavee RM (1981) Selective predation by Favella ehrenbergii (Tintinnida) on and among dinoflagellates. Biol Bull 160:136-145

Turner JT, Tester PA (1997) Toxic marine phytoplankton, zooplankton grazer, and pelagic food webs. Limnol Oceanogr 42:1203-1214

Watras CJ, Garcon VC, Olson RJ, Chisholm SW, Anderson DM (1985) The effect of zooplankton grazing on estuarine blooms of the toxic dinoflagellate Gonyaulax tamarensis. J Plankton Res 7:891-908

Yashumoto T (1990) marine microorganism toxins-an overview. In: Graneli E, Sundstrom B, Edler L, Anderson DM (eds) Toxic marine phytoplankton. Elsevier, New York, p 3-8

Zar JH (1984) Biostatistic analysis. Prentice-Hall, Englewood Cliffs, NJ

Submitted: September 1, 2000; Accepted: March 28, 2001 Proofs received from author(s): July 20, 2001 